\title{
Good Governance on Village Fund Management with The Use of Information Technology as A Moderating Variable
}

\section{Safrizal, Taufeni Taufik \& Yesi Mutia Basri*}

The Faculty of Economics and Business, Universitas Riau, Pekanbaru, Indonesia

* yesimutiabasri@lecturer.unri.ac.id

\begin{tabular}{|c|c|}
\hline Article Info & Abstract \\
\hline Received : :2021-06-10 & \multirow{4}{*}{$\begin{array}{l}\text { This study contains testing and analysis of the effect of good } \\
\text { governance principles on the management of village funds, as well } \\
\text { as the use of information technology as moderation. The population } \\
\text { in this study was } 197 \text { villages in Indragiri Hilir Regency with a } \\
\text { sample of } 132 \text { villages. The sampling technique used was } \\
\text { proportional stratified random sampling based on the village index. } \\
\text { The data were analyzed using SPSS. The finding showed all } \\
\text { influential hypotheses, namely good governance with the principles } \\
\text { of transparency, accountability, and community participation in the } \\
\text { management of village funds, and moderated by the use of } \\
\text { information technology. }\end{array}$} \\
\hline Accepted : :2022-01-12 & \\
\hline Published : 2022-01-31 & \\
\hline $\begin{array}{l}\text { Key words: transparancy; } \\
\text { accountability; community } \\
\text { participation; use of information } \\
\text { technology; village fund } \\
\text { management }\end{array}$ & \\
\hline
\end{tabular}

\section{INTRODUCTION}

Village fund management becomes part of village finance implementation, guided by Minister of Home Affairs Regulation No. 20 Year 2018 to be the basis for the village in managing finances. Obviously, the village has an important role to strategically assist the local government in the process of governance, which is principled "money follows function and money follows program, meaning funding follows the functions of government as obligations and responsibilities of the village" (Kemenkeu, 2017).

According to Law No. 6 of 2014 on village funds accompanied by technical guidance on the implementation of Central Government Regulation (PP) No. 43 year 2014 stated "village funds are the transfer of state budgets and expenditures to districts / cities intended for villages to fund the implementation of government, implementation of development, development and empowerment of the community". The local funding (DD) program in Indonesia began in 2015 amounting to Rp. 20.7 trillion for 74,093 villages, Riau Province amounted to Rp. 445.6 billion, and Rp. 175,723,073,000 in Indragiri Hilir district, with the provision of such large funds is highly recommended for villages to manage village funds effectively and efficiently starting from planning, implementing, administrating, reporting and accountability (Kemendagri, 2018).

The issue that occurred over the management of DD became an important concern for the government. By looking at the study of the State Financial Accountability Agency (BKN) of the House of Representatives on the results of the examination of the Corruption Eradication Commission (KPK) for village fund planning has not been done based on mapping the problems and needs of the village and the absence of regulation on the determination of village government accounting standards.

Furthermore, several issues related to the aspects of its implementation comprise budget management time frame that is difficult to comply with, the unavailable standard price rules of service, as well as the low plan of the use and accountability of local government budged (APBD). Obviously, many villages still have experienced delays in disbursement of village funds (Prasetya, 2020).

Additionally, the issue of supervision aspects still become controversial, since the supervision planning that has not considered the risks, has not fully included the evaluation of the suitability of the Village Budget with the scale of priority use, and the lack of follow-up 
improvement of the supervisory report (DPRRI, 2019). The village fund corruption case is one form of evidence of this weak supervision and negligence.

As stated by (Cahyono et al., 2020) there are three problems over the phenomenon of misuse of management (corruption of village funds) such as the weak capacity in managing village funds, the large granting of funds which is not followed by the strengthening of community and institutional democracy of the village, and the difficulty of the government to supervise the management of village funds.

Referring to the issue of village fund management in Indragiri Hilir Regency, which is currently based on the Report of The Results of Examination Semester (LHPS) II in 2019, is still experiencing problems. One of them is low supervision on the management of village funds, seen from the case of embezzlement of village funds through corruption actions that cost the state Rp309,589,335, in addition to the time frame of low budget management sites seen from the delay in the distribution of village funds (Agustina, 2018).

The success of village fund management in an area is seen from the aspect of good governance. Good governance requires every public official to be responsible and accountable for all attitudes, behaviors and policies in carrying out duties, functions and authorities to the public (Dianingrum, 2018). The implementation of good governance is very important to be applied as one of the ideas in considering the success of village fund management with a number of principles that can be used as indicators in practice, management implementation, and a number of problems faced, especially in its utilization (Cahyono et al., 2020). Good governance is a priority for the government in running the bureaucratic wheel, it is also applied to the Indragiri Hilir District-patent for good governance as a prevention of corruption (Siregar, 2018). According to Permendagri No. 20 of 2018, which describes "good governance as a good government and not bad governance in the administration of government". Therefore, village fund management must contain the principles of good governance, including transparency, accountability and community participation (Hidayah \& Wijayanti, 2017).

First, transparency as a principle of government openness provides information on public resource management activities (finance) to the public (Kristianten, 2006). Transparency of financial management will create a parallel line between government and society. Thus, the creation of a clean, effective and responsive government to the aspirations of the community (Mardiasmo, 2004). Transparency has an effect on village fund management (Wafirotin \& Septiviastuti, 2019) (Gayatri et al., 2017). However, (Singh \& Kaur, 2015) transparency as a principle of good governance is not considered to respond adequately to the expectations and demands of the community, thus the openness that has not been managed to the maximum in the internal spending affairs of the village government (Utomo et al., 2018).

Second, accountability as a form of government obligation to account for the management, control of resources, and implementation of policies mandated in order to achieve goals. Research by (Taufik \& Safrizal, 2021), (Fitriyani et al., 2018), (Susliyanti, 2015) shows that accountability affects village fund management. However, on the other hand, the aspect of accountability is only considered as physical accountability and the need for improvement in terms of administration and information (Hidayah \& Wijayanti, 2017).

Third, the principle of community participation, namely the implementation of villages involving village institutions and community elements in good governance as the driving force for accelerating the implementation of village government (Astuti \& Yulianto, 2016). Community participation in village fund management began planning, decision making, supervision and evaluation (Taufik \& Safrizal, 2021). In line with (Wafirotin \& Septiviastuti, 2019) research, (Chomariyah et al., 2016) showed that community participation has an effect on DD management. On the other hand, community participation is considered minimal due to the lack of socialization from the government and public education on village fund management (Kairupan \& Mantiri, 2020), (Tumbel Mentari, 2014). 
Research on good governance is now something interesting to be researched on the basis of inconsistencies in the results of previous research. Therefore, it becomes an opportunity of the use of information technology as moderation in this study.

The use of information technology as a supporter of good governance towards village fund management will create effectiveness and efficiency in the preparation of planning, budgeting, implementation, administration and accountability (www.BPK.go.id). Transparency as a principle of public openness to the management of village funds, of course, will be better with the help of information technology that becomes strategic in strengthening supervision of financial management, especially funds so that there are no irregularities in management and use, so that the utilization of IT becomes a factor in the success of supervision and assessment by the community (Muhlizi, 2016). The research (Udomsilp, 2013), (Setiyadi, 2003) showed the use of information technology is able to support transparency over village fund management. Meanwhile, (Rika Gamayuni, 2020) the utilization of information technology cannot reflect the quality of information including financial information, due to the limitations of village devices to understand the information technology used, so that transparency in the information produced does not reflect the actual circumstances of village fund management.

Furthermore, the utilization of IT will support the creation of public accountability seen from the management of village funds for reliable financial reporting, through the management of data, information, management systems and electronic work processes as a form of accountability to the community (Riyadi \& Kurnadi, 2020). Research by (Bawono et al., 2020), (Nugrahaningsih, 2018), (Jorge de Jesus \& Eirado, 2012) shows that the use of information technology is able to moderate the accountability of village fund management. However, (Rika Gamayuni, 2020) showed that information technology does not have the ability to moderate the accountability of village funds.

The use of information technology is also able to moderate the creation of increased community participation in village fund management by opening up a wide space, creating good community and village government interactions with the loss of interaction boundaries between space and time. So that the presence of information technology can be a forum for participatory community empowerment over village fund management, with the aim of increasing village potential, marketing and accelerating access and information services (Riyadi \& Kurnadi, 2020). (Noviantoro et al., 2019), (Nurhadianto et al., 2006) that the use of technology was able to open the community interaction room with the village government on the management of village funds. However, (Utomo et al., 2018) the use of information technology is considered drinking as a form of participation in good governance of village fund management.

In addition to the differences in the results of previous research, the novelty of theory is also used on this research in the form of stewardship theory which is considered very relevant to be used as a substitute for agency theory in public sector organizations.

In accordance with the problems that still occur in the management of village funds, as well as the differences in previous research so that it becomes an opportunity for research entitled Good Governance on Village Fund Management with The Use of Information Technology as A Moderating Variable. The purpose of this research is to analyze the effect of good governance on the management of village funds in Indragiri Hilir Regency. This research is important for readers and stakeholders as a means of evaluation and knowledge of the importance of managing village funds to be managed with good governance principles accompanied by the use of information technology

\section{LITERATURE REVIEW}

Stewardship theory is applied to the accounting of public sector organizations such as government organizations, government management is required to provide services (acting as stewards / stewards) for the benefit of the principal. This suggests that management is not 
motivated by individual goals, but rather focuses on key objectives for the benefit of the organization. Thus management in the government environment is more dominant acting as steward than as an agent. This is supported by (Morgan et al., 1996), (Van Slyke, 2007) that government management acts more as stewards, so it is very relevant if the theory of stewardship is applied to the research of public sector organizations, especially government rather than agency theory.

The implications of stewardship theory, explaining the existence of the Village Government (steward) as an institution that can be trusted and act in accordance with the public interest by carrying out duties and functions appropriately for the welfare of the community (principal). The village government carries out its duties, making financial accountability in the form of presentation of accountable and transparent financial statements. Accessibility of financial statements is one form of transparency of the village government (steward) to the community (principal) for the management of village funds by providing access to financial information to the community so that public services and community welfare can be achieved to the maximum. In addition, transparency provides open and honest information to the community as a party that has the right to know openly and thoroughly the village government in managing village funds mandated to him. Accountability is closely related to the instruments of control activities in achieving public service results and delivering them transparently to the community on the management of village funds. To carry out its responsibilities as a village fund manager, the village government is expected to maximize all its capabilities and expertise by utilizing information technology to achieve effective management.

\section{Village fund management}

Village financial management includes village funds which are funds transferred by the central government to villages in the context of equitable development and empowerment for villages starting from planning, implementation, administration, reporting, and financial accountability (Kemendagri, 2018).

\section{Transparancy}

Transparency as part of good governance is defined as a principle that guarantees access or freedom for everyone to obtain information about the administration of government, which is information, open and disclosure about policies, the process of making and the results achieved (Mardiasmo, 2004).

\section{Accountability}

Accountability is a form of responsibility for implementing the organization's mission in achieving the goals that have been set through the media of accountability which is carried out periodically from planning to implementation, monitoring to reporting, as part of good governance in managing village funds so that it can run well (Gayatri et al., 2017).

\section{Community participation}

Community participation describes how much the community is involved in managing village funds, the perceived influence and role of the community in the decision-making process, planning and budget implementation from planning to evaluation. (Astuti \& Yulianto, 2016).

\section{Use of information technology}

The utilization of information technology is the act of utilizing a set of tools and networks that help generate, manipulate, store, and convey information (PP No. 65 of 2010). Information technology includes computers (mainframe, mini, micro), software, databases, networks (internet) as data processing in generating information (Tata Sutabri, 2014). 


\section{Hypothesis development}

\section{The effect of transparency on village fund management}

Transparency as a good governance principle for the management of village funds shows the openness of government information to the public in managing resources (finance) (Kristianten, 2006). Transparency of village fund management means all parties can know the whole process openly. In addition, it is sought so that the villagers can receive information about the objectives, objectives, results, benefits obtained from each activity that uses the funds (Paranoan, 2015). In line with PP No.24 of 2005, transparent is to provide open and honest financial information to the public based on the consideration that the public has the right to know openly and thoroughly starting from the policy process, planning, implementation, supervision and control that is easily accessible to all parties who need such information. The research (Gayatri et al., 2017), (Basri et al., 2021) showed transparency affects village fund management.

Ha1: Transparency has an effect on Village Fund Management

\section{The effect of accountability on village fund management}

Accountability as a form of responsibility to the public which is an important principle in good governance for the management of village funds (Astuti \& Yulianto, 2016). Accountability is defined as an obligation to convey accountability for actions taken collectively to those who have the right and authority to accept and hold such liability. Accountability to the management of village funds shows that financial liability obligations are presented honestly and comply with the law (regulation), managerial by conducting good management to avoid inefficiencies on the use of funds. Accountability also needs to be applied to programs and policies that are in the public interest and the objectives of the organization. In addition, accountability is very important for the financial management of the village, as well as village funds that must be accounted for starting from planning, implementation to reporting on the implementation and use of funds. This is certainly in line with (Wafirotin \& Septiviastuti, 2019), (Fitriyani et al., 2018) which shows that accountability affects village fund management.

Ha2: Accountability affects Village Fund Management.

\section{The effect of community participation on village fund management}

Participation is defined as village implementation, involving village institutions and community elements in good governance as the driving force to accelerate the implementation of village government (Astuti \& Yulianto, 2016). In addition, community participation either directly or through legitimate representatives becomes the main key of good government in financial management (Chomariyah et al., 2016), with the community participation applied will have a positive impact where the government is easier to manage village budget finances and of course the community can know how the budget process and its involvement. Participation of village fund management that describes community participation in decision making, drafting and implementation of budgets (Tumbel Mentari, 2014). Thus community participation as the principle of good governance certainly has relevance as an idea for village fund management both practices, implementation of management and utilization (Cahyono et al., 2020). Research (Wafirotin \& Septiviastuti, 2019), (Basri et al., 2021) showed that community participation has an effect on village fund management

Ha3: Community participation affects village fund management

\section{The effect of transparency on village fund management is moderated by the utilization of information technology}

Information technology that includes computers, software, networks and others related to technology (Wilkinson, 2000), computers as part of information technology is a tool that is able to multiply human capabilities and do something that humans may not be able to do. Thus, the utilization of information technology will help the activities of an organization more efficiently ijesh.unri.ac.id 
and effectively both at the administration and village groups, the utilization of information technology will support the government as an effort to enforce good governance through the utilization of networks in improving transparency, accountability and community participation in managing village funds (Udomsilp, 2013). Transparency as a form of openness to the public over the management of village funds, of course, will be better with the help of information technology. Transparency of information to the public is very important for the community in controlling government policies on financial management both central and local including village government. The use of information technology becomes strategic in strengthening the supervision of financial management so that there are no irregularities in its management and use. Therefore, the support of the utilization of information technology in managing village funds is a factor in the success of supervision and assessment by the community (Muhlizi, 2016). The research (Udomsilp, 2013) showed that the use of information technology is able to support the influence of transparency on village fund management.

Ha4: Transparency has an effect on Village Fund Management Moderated Utilization of Information Technology

\section{The effect of accountability on village fund management moderated the utilization of information technology}

The principle of accountability as a form of government obligation to account for the management and control of resources and the implementation of policies entrusted in order to achieve goals. In order to support accountability for village fund management, information technology utilization of reliable financial reporting is required. The use of information technology includes data processing, information processing, management systems and electronic work processes, in addition to the utilization of IT advances will also make it easier for public services to be easily and cheaply accessible by the community and will assist village officials in managing village funds finance with the help of computers (Riyadi \& Kurnadi, 2020). So that the utilization of information technology is considered capable to visit the accountability of the village government for the management of DD. Research by (Bawono et al., 2020), (Jorge de Jesus \& Eirado, 2012) shows that the use of information technology is able to moderate accountability to village fund management.

Ha5: Accountability has an effect on Village Fund Management moderated utilization of information technology

\section{The influence of community participation on village fund management moderated the utilization of information technology}

The use of information technology will be of positive value through increased community participation by opening up a large enough space, so that there is better interaction between the community and the village government, proven to be the loss of the boundaries of interactions that are built. On the other hand, the villagers have taken advantage of the advancement of information technology, so that the presence of information technology can certainly be a forum for community empowerment over village fund management, with the aim of increasing the potential of villages, marketing and accelerating access and information services (Riyadi \& Kurnadi, 2020). The use of information technology that develops through the internet network, the use of social media as an information field introduces the village, in addition the activeness of the community in using technology will open the space of community interaction with the village government undergoes positive changes. So that the utilization of information technology can increase public participation in village fund management (Noviantoro, 2019). The research (Nurhadianto et al., 2006), (Sugiarti \& Yudianto, 2017) showed the utilization of information technology has a significant influence on the village's management of village funds.

Ha6: Community participation has an effect on village fund management moderated utilization of information technology 


\section{METHODS}

This study was conducted in Indragiri Hilir Regency part of 12 regencies or cities in Riau Province, with an area of $11,606 \mathrm{~km}^{2}$ and the capital city located in Tembilahan. The object of this study was the management of village funds in Indragiri Hilir Regency, Riau Province. The population of this research was the village of Indragiri Hilir regency as the recipient of village funds, as many as 197 villages from 19 sub-districts. Sample techniques in the form of stratified random sampling taken according to the portion based on village index (advanced, developed, and lagging), with research respondents namely village officials, BPD, and local communities. This study used quantitative approach with primary sources, obtained directly and indirectly (through online media) through the dissemination of questionnaires. The data came from respondents' responses in the villages of Indragiri Hilir Regency.

\section{RESULTS}

The results of the research are shown in form of descriptive statistic test, data quality, classical assumptions to discussion and finding of the research:

Descriptive statistical test result

Table. 1. Descriptive Statistics Test Results

\begin{tabular}{lrrrrr}
\hline \multicolumn{7}{c}{ Descriptive Statistics } & & \\
& \multicolumn{1}{c}{$\mathrm{N}$} & Minimum & Maximum & Mean & $\begin{array}{c}\text { Std. } \\
\text { Deviation }\end{array}$ \\
\cline { 2 - 6 } & Statistic & \multicolumn{1}{c}{ Statistic } & \multicolumn{1}{c}{ Statistic } & Statistic & \multicolumn{1}{c}{ Statistic } \\
\hline Y (Village Fund & 102 & 1.00 & 5.00 & 3.6954 & 1.0348 \\
Management) & & & & & \\
X1 (Transparency) & 102 & 1.00 & 5.00 & 3.6458 & 1.0143 \\
X2 (Accountability) & 102 & 1.00 & 5.00 & 3.8222 & 1.0821 \\
X3 (Society participation) & 102 & 1.00 & 5.00 & 3.7643 & 1.0058 \\
Z (Utilization of Information & 102 & 1.00 & 5.00 & 3.7260 & 1.0078 \\
Technology) & & & & & \\
\hline Valid N (listwise) & 102 & & & & \\
\hline Source: Processed Data (2021) & & & & &
\end{tabular}

Based on the table above, descriptive statistical test results show a minimum value of 1.00, a maximum value of 5.00, with an average of $3.6454-3.8222$, and a standard deviation of $1.0058-1.0821$ and position criteria of $3.20-5.00$. In response to this result, the management of Indragiri Hilir district funds is included in the good category.

\section{Data validity test result}

According to the result of data validity test, the statements items regarding the variables of village fund management, transparency, accountability, community participation, and utilization of information technology is higher than $\mathrm{r}$ table ( $\mathrm{r}$ calculate $>0.195$ ). It shows that the statements in all these research variables are valid.

\section{Data reliability result}

The internal consistency of the reliability value can be measured above 0 and 1 . The higher the value also indicates the higher the level of validity. As for the values and reliability of alpha and composite reliability should be higher than 0.700 . The reliability testing for each variable of this research obtains Cronbach Alpha $>0.70$. Based on this result, the data of this research is reliable. 
Good Governance on Village Fund Management with The Use of Information Technology as A Moderating Variable

Data normality test results

Table. 2. Data Normality Test Results

\begin{tabular}{llr}
\hline \multicolumn{2}{c}{ One-Sample Kolmogorov-Smirnov Test } \\
\hline $\mathrm{N}$ & \multicolumn{2}{c}{ Unstandardized Residual } \\
\hline Normal Parameters ${ }^{\mathrm{a}, \mathrm{b}}$ & & 102 \\
& Mean & .0000000 \\
Most Extreme Differences & Std. Deviation & 2.02892393 \\
& Absolute & .087 \\
& Positive & .087 \\
Kolmogorov-Smirnov Z & Negative & -.053 \\
Asymp. Sig. (2-tailed) & & .875 \\
& & .429 \\
\hline a. Test distribution is Normal. & & \\
b. Calculated from data. & & \\
Source: Processed Data (2021) & &
\end{tabular}

The table above shows the normality test with kolmogorov-Smirnov, and obtained significance of $0.429>0.005$. Likewise, the study meets the assumption of normality.

Multicolerity test results

Table 3. Multicolinearity Test Results

\begin{tabular}{lccc}
\multicolumn{1}{c}{ Model } & \multicolumn{2}{c}{ Unstandardized Coefficients } \\
\cline { 2 - 3 } & $\mathrm{B}$ & \multicolumn{1}{c}{ Std,Error } \\
\hline X1 (Transparency) & .514 & .151 \\
X2 (Accountability) & .258 & .074 \\
X3 (Community Participation) & .604 & .138 \\
\hline
\end{tabular}

a. Dependent Variable: Village Fund Management

Source: Processed Data (2021)

Based on table 3 above, it can be seen that the default error value $<1.00$ and the beta value $<$ 1.00 , then the regression model is free of multicolinearity.

Heteroskedastisity test results

Table 4. Heteroskedastisity Test Results

Coefficients $^{\mathrm{a}}$

\begin{tabular}{llrrrr}
\hline \multirow{2}{*}{ Model } & \multicolumn{2}{c}{ Unstandardized Coefficients } & \multicolumn{1}{c}{ t } & \multicolumn{1}{l}{ Sig. } \\
\cline { 2 - 3 } & \multicolumn{1}{c}{ B } & Std. Error & & \\
\hline 1 (Constant) & 1.741 & .515 & 3.383 & .001 \\
\hline X1 (Transparency) & .047 & .093 & .498 & .620 \\
X2 (Accountability) &. .028 & .046 & -.603 & .548 \\
X3 (Community Participation) & .004 & .086 & .050 & .960 \\
\hline
\end{tabular}

a. Dependent Variable: ABS_MOD

Source: Processed Data (2021)

Based on table above, it appears that the significance value $>0.05$, then it can be said that the regression model is free from heteroskedastisitas.

Autocorrelation test results

Table 5. Autocorrelation Test Results

\begin{tabular}{ccc}
\hline & Model Summary $^{\mathbf{b}}$ & \\
\hline Model & Durbin-Watson & Information \\
1 & 2.028 & No Autocorrelation \\
\hline
\end{tabular}

Source: Processed Data (2021)

The autocorrelation test result in the table above shows the value of Durbin-Watson 2028 is between DU and 4 - DU (1,738 and $4-1,738)$, then the research model there is no autocorrelation. 


\section{Determination coefficient test result}

The result of the coefficient of determination for multiple linear regression analysis was $95.6 \%$. That is, the contribution of independent variable influence to dependents is $95.6 \%$. While the remaining 3.4\% was influenced by other variables not included in this research model, such as commitment, apparatus competence and others.

\section{Multiple linear regression analysis results}

Based on the tests conducted, the equations obtained multiple linear regression analysis for the first and second hypotheses are as follows:

$$
\mathrm{Y}=230+0.514 \mathrm{X} 1+0.256 \mathrm{X} 2+0.604 \mathrm{X} 3+\mathrm{e}
$$

Table 6. Hyphotesis Test Results

\begin{tabular}{|c|c|c|c|c|}
\hline Hyphotesis & Information & Taraf & Sig. & Conclusion \\
\hline $\begin{array}{c}\mathrm{H} 1 \\
\text { (Transparency) }\end{array}$ & & 0,05 & 0,001 & Accepted \\
\hline $\begin{array}{c}\mathrm{H} 2 \\
\text { (Accountability) }\end{array}$ & & 0,05 & 0,001 & Accepted \\
\hline $\begin{array}{c}\mathrm{H} 3 \\
\text { (Community Participation) }\end{array}$ & & 0,05 & 0,000 & Accepted \\
\hline $\mathrm{H} 4$ & Equation 1 & 0,05 & 0,000 & Accepted \\
\hline $\begin{array}{c}\text { (Transparency } * \text { utilization of information } \\
\text { technology) }\end{array}$ & $\begin{array}{l}\text { Equation } 2 \\
\text { Equation } 3\end{array}$ & $\begin{array}{l}0,05 \\
0,05\end{array}$ & $\begin{array}{l}0,000 \\
0,001\end{array}$ & \\
\hline $\mathrm{H} 5$ & Equation 1 & 0,05 & 0,000 & Accepted \\
\hline $\begin{array}{c}\text { ((Accountability*utilization of information } \\
\text { technology) }\end{array}$ & $\begin{array}{l}\text { Equation } 2 \\
\text { Equation } 3\end{array}$ & $\begin{array}{l}0,05 \\
0,05\end{array}$ & $\begin{array}{l}0,000 \\
0,018\end{array}$ & \\
\hline $\begin{array}{c}\text { H6 } \\
((\text { Community Participation*utilization of } \\
\text { information technology) }\end{array}$ & $\begin{array}{l}\text { Equation } 1 \\
\text { Equation } 2 \\
\text { Equation } 3\end{array}$ & $\begin{array}{l}0,05 \\
0,05 \\
0,05\end{array}$ & $\begin{array}{l}0,000 \\
0,005 \\
0,013\end{array}$ & Accepted \\
\hline
\end{tabular}

Source: Processed Data (2021)

\section{DISCUSSION}

Table 6 shows that all research hypotheses are accepted, this decision is seen by doing so by comparing the value of significance with the level of error of $5 \%$.

\section{The effect of transparency on village fund management}

Transparency as a good governance principle for the management of village funds shows the openness of government information to the public in managing resources (finance) (Kristianten, 2006). The transparency of village fund management shows that it is not up to all parties to know the whole process openly. In addition, so that the villagers can receive clear information about the objectives, objectives, results, and benefits obtained for the management of the DD (Paranoan, 2015). Along with PP No. 24 year 2005, transparent as the completeness of financial information that is open and honest to the public on the basis of rights owned, transparency is carried out thoroughly from the process of policy, planning, implementation, supervision and control by providing sufficient access to information use, the results of the implementation of the program, and of course can accommodate the management of village funds by the public. In line with the implementation of stewardship theory that shows the relationship between stewards and principals, the village government as stewards will certainly carry out its function as a trustee in order to realize transparency over all activities of the village government, especially in the management of village funds, on the basis of consideration that transparency is an honest information disclosure to the public (the public) as a party that has the right to know all information on pe government's responsibility in managing village funds entrusted to it. Thus, the principle of transparency has a close relationship for the government in running the wheel of the government. This is certainly in line with the research of (Gayatri et al., 2017), 
Good Governance on Village Fund Management with The Use of Information Technology as A Moderating Variable

Widiyanti (2016) which showed that trans-paransi significantly influenced the management of village funds.

\section{The effect of accountability on village fund management}

Accountability as a form of responsibility to the public which is the most important aspect in good governance for the management of DD (Astuti \& Yulianto, 2016). The implementation of accountability for the management of village funds shows that there is a financial liability for honest and law-abiding statements (regulations) for the use of village funds and is done correctly with evidence of authoritariany. In addition, accountability also concerns the managerial sphere by conducting effective and efficient lobbying that is the responsibility of the village government. Not only that, accountability is also applied to the realm of programs and policies, with evidence that the government has implemented quality programs that support the achievement of organizational objectives and will certainly account for all policies that have been set in accordance with the allocation- yes, so that accountability for the management of village funds becomes a necessity for every village official starting from planning to reporting on the implementation of village fund management. In accordance with the theory of stewardship theory the government acts as stewards of institutions that are believed to act in line with the expectations of the public will certainly account for its activities to the community as principal for the management of village funds, so that accountability becomes an instrument in control activities of government achievements to the public. The results of this study are in line with (Wafirotin \& Septiviastuti, 2019), (Fitriyani et al., 2018) accountability influence on village fund management.

\section{The effect of community participation on village fund management}

Participation is defined as the implementation of village bureaucracy by involving village institutions and community elements in good governance as the driving force to accelerate the implementation of village government (Astuti \& Yulianto, 2016). In addition, community participation either directly or indirectly (representative institutions) that are legitimately the main key of good government in financial management (Chomariyah et al., 2016), with the participation of the community applied will have a positive impact where the government is easier to manage the village budget finances and of course the community can know how the budget process is carried out, because of the existence of self-management (Hasniati, 2016). Community participation in the management of DD, describing community participation in decision making on village fund programs, proposing budget plans by being involved in village plenary meetings, and participating in monitoring, assessment, and even appreciation for the implementation of village budgets (Djumadi, 2015). Thus, community participation as the principle of good governance certainly has relevance as an idea for village fund management both practice, implementation of management and utilization (Cahyono et al., 2020). The results of this hypothesis test are in line with (Wafirotin \& Septiviastuti, 2019), (Basri et al., 2021), the influence of community participation on DD management.

\section{The effect of transparency on village fund management with the use of information technology as a moderation variable}

The use of IT which includes hardware, software and networks is closely related to technology (Wilkinson, 2000), computers that are part of information technology as a tool that can do the work as well as human capabilities even jobs that humans may not do. Thus, the utilization of IT will help the activities of an organization more efficiently and effectively both at the administrative level and village groups, the utilization of information technology will support the government as an effort to create the principle of transparency over good governance towards the management of DD (Information Village Fund) (Udomsilp, 2013). Transparency as a form of openness to the public over the management of village funds, of course, will be better with the help of information technology. Transparency of information to the public is very important for the community in controlling government policies on financial management both 
central and local including village government. The use of information technology is increasingly strategic as an effort to strengthen supervision of DD management, in order to avoid irregularities in its management and utilization. Therefore, the support of the utilization of information technology in managing village funds is a factor in the success of supervision and assessment by the community(Muhlizi, 2016). The research ) (Udomsilp, 2013), Setiyadi (2013) showed the use of information technology is able to support the influence of transparency on the management of DD.

\section{The effect of accountability on village fund management with the utilization of information technology as a moderation variable}

Accountability is moderated by the utilization of information technology on the management of village funds. The principle of accountability as a form of government obligation to account for the management and control of resources and the implementation of policies charged to him to achieve the vision and mission of the organization. In order to moderate accountability to DD management, it is necessary to use information technology to achieve reliable financial reporting. The use of information technology is done for data processing, information, management systems and work processes are carried out electronically, not only that, the use of IT advances will also facilitate the implementation of public services with easy and cheap access to the community, certainly will ease the burden of village apparatus in managing village funds due to the presence of computer assistance (Kurnadi, 2020). So that the use of information technology becomes very important to be applied both in the scope of management accountability, programs and policies, and especially in the management of finan-sial responsibility, from planning to reporting on the management of village funds. The acceptance of this hypothesis is supported by research by (Bawono et al., 2020), (Jorge de Jesus \& Eirado, 2012) the ability to use information technology to moderate accountability to DD management.

The influence of community participation on village fund management with the

The use of information technology will be of positive value through increased community participation by opening up a large enough space, so that there is better interaction between the community and the village government, proven to be the loss of the boundaries of traditional interactions. On the other hand, the villagers have taken advantage of the advancement of information technology, proven by the ownership of telephones with internet access, so that the presence of information technology can certainly be a forum for community empowerment over village fund management, with the aim of increasing the potential of villages, marketing and accelerating access and information services (Riyadi \& Kurnadi, 2020). The use of information technology that develops through the internet network, the use of social media as an information field introduces the village, in addition to the activeness of the community in using technology will open the community interaction space with the village government, one of which provides input or information on problems in the village, not only that the use of IT can also be a forum to provide criticism and input for the village that can be used as evaluation or consideration for the village in running the government, as well as being a place to give appreciation for the implementation of village funding programs. So that the application of the use of IT can increase community participation in village fund management (Noviantoro, 2019). (Nurhadianto et al., 2006), (Sugiarti \& Yudianto, 2017) showed the utilization of information technology has a significant influence on the village's management of village funds.

\section{CONCLUSIONS AND SUGGESTIONS}

\section{Conclusion}

The above discussion has demonstrated that all the research variables are influential, as well as moderating the management of village funds in Indragiri Hilir Regency. Transparency shows the openness of information that is easily accessible by the public, while accountability shows 
Good Governance on Village Fund Management with The Use of Information Technology as A Moderating Variable

its accountability as a stewardship in the theory of stewardship to the principal, and community participation shows the involvement of the community in the implementation of village funds. Thus, the higher the transparent level, accountability and community participation, the better the level of village fund management. In addition, the utilization of information technology that is able to moderate research shows that the help of information technology capabilities has made the better level of village fund management.

\section{Suggestion}

Based on the findings of the study, discussions and conclusions that show the implementation of good governance on the management of village funds within the Indragiri Hilir district which of course has limitations both in terms of research scope, cost and time. Therefore, it is suggested for further researchers to conduct the research by;1) expanding the scope of research, 2) conducting the interviews to get and explore more information in the next research, 3) adding other exogenous variables.

\section{REFERENCES}

Agustina, R. A. (2018). Awal Juni Batas Akhir Pencairan Dana Desa, Dewan Minta Pemkab Inhil Lakukan Percepatan. M.Goriau.Com. https://www.goriau.com/berita/baca/awal-junibatas-akhir-pencairan-dana-desa-dewan-minta-pemkab-inhil-lakukan-percepatan.html

Astuti, T. P., \& Yulianto, Y. (2016). Good Governance Pengelolaan Keuangan Desa Menyongsong Berlakunya Undang-Undang No. 6 Tahun 2014. Berkala Akuntansi Dan Keuangan Indonesia, 1(1), 1-14. https://doi.org/10.20473/baki.v1i1.1694

Basri, Y. M., Marianti, T. D., \& Rofika. (2021). Pengelolaan Keuangan Desa: Analisis Faktor yang Mempengaruhinya. Journal of Chemical Information and Modeling, 8(1), 34-50. https://doi.org/10.30656/jak.v8i1.2379

Bawono, I. R., Kinasih, A. D. M., \& Rahayu, A. K. (2020). Factors Affecting Accountability of Village Fund Management through Implementation of the Village Financial System (SISKEUDES). Journal of Accounting and Investment, 21(3), 471-491. https://doi.org/10.18196/jai.2103160

Cahyono, H., Aziz, N. L. L., Nurhasim, M., Rahman, A. R., \& Zuhro, R. Si. (2020). Pengelolaan Dana Desa Studi dari Sisi Demokratis dan Kapasitas Pemerintahan Desa. In Proposal SIMLITAMAS. https://www.kemenkeu.go.id/media/6749/buku-pintar-danadesa.pdf

Chomariyah, Hudi, N., \& Ariyanto, B. (2016). Participation Principle On The 2014 Village Law In Coastal Village. International Journal of Business, Economics and Law, 10(4), 33-40. http://ijbel.com/wp-content/uploads/2016/09/K10 204.pdf

Dianingrum, S. (2018). Implementasi Good Governance dalam Pengelolaan Dana Desa dengan Prespektif Syariah di Desa Mliriprowo Kecamatan Tarik Kabupaten Sidoarjo. El Muhasaba Jurnal Akuntansi, 9(1), 1-16. https://doi.org/https://doi.org/10.18860/em.v1i1.5407

DPRRI. (2019). Pengelolaan Dana Desa Masih Bermasalah. Dpr.Go.Id. https://www.dpr.go.id/berita/detail/id/25283/t/Pengelolaan+Dana+Desa+Masih+Bermasalah

Fitriyani, L. Y., Marita, M., Widyastuti, W., \& Nurahman, R. W. (2018). Determinants of Village Fund Allocation. Jurnal Akuntansi Multiparadigma, 9(3), 526-539. https://doi.org/10.18202/jamal.2018.04.9031

Gayatri, G., Latrini, M. Y., \& Widhiyani, N. L. S. (2017). Transparansi dan Akuntabilitas Pengelolaan Keuangan Dana Desa untuk Mendorong Kemandirian Masyarakat Pedesaan. Jurnal Ekonomi Kuantitatif Terapan, 10(2), 175-182. https://doi.org/10.24843/jekt.2017.v10.i02.p07 
Hidayah, N., \& Wijayanti, I. (2017). Akuntabilitas Pengelolaan Dana Desa (Dd) Studi Kasus Pada Desa Wonodadi Kecamatan Ngrayun Kabupaten Ponorogo. Jurnal AKSI (Akuntansi Dan Sistem Informasi), 1(2), 1-7. https://doi.org/10.32486/aksi.v1i2.114

Jorge de Jesus, M. A., \& Eirado, J. S. B. (2012). Relevance of accounting information to public sector accountability: A study of Brazilian federal public universities. Tékhne, 10(2), 87-98. https://doi.org/10.1016/j.tekhne.2012.10.001

Kairupan, S. B., \& Mantiri, J. (2020). Openness of Public Information in the Management of Village Funds in North Minahasa Regency. Advances in Social Science, Education and Humanities Research, 473(Icss), 1-4. https://doi.org/10.2991/assehr.k.201014.001

Kemendagri. (2018). Berita Negara Pengelolaan Keuangan Desa. In Pengelolaan Keuangan Desa: Vol. Nomor 20 (Issue 611). https://www.jogloabang.com/sites/default/files/dokumen/bn611-2018-permendagri-202018.pdf

Kemenkeu. (2017). Buku Saku Dana Desa. In Kementerian Keuangan Republik Indonesia.

Kristianten. (2006). Transparansi Anggaran Pemerintah. Rinaka Cipta.

Mardiasmo. (2004). ). Akuntansi Sektor Publik. Andi.

Morgan, D., Bacon, K. G., Bunch, R., Cameron, C. D., \& Deis, R. (1996). What Middle Managers Do in Local Government: Stewardship of the Public Trust and the Limits of Reinventing Government. Public Administration Review, 56(4), 359-366. https://doi.org/10.2307/976377

Muhlizi, A. F. (2016). Penguatan Akses Informasi Publik Melalui Teknologi Informasi Sebagai Bentuk Transparansi Pengelolaan Keuangan Negara. Jurnal Rechts Vinding: Media Pembinaan, 5(2), 149-163. http://rechtsvinding.bphn.go.id/ejournal/index.php/jrv/article/view/137

Nugrahaningsih, P. (2018). Applied Technology for Village Fund Management. Journal of Research and Applications Accounting and Management, 3(1), 18-26. https://doi.org/10.18382/jraam.v3i1.18

Nurhadianto, T., Agustina, F., Khoiriah, Y., \& Saputri, U. T. (2006). The principles of good governance. In Managing Defence in a Democracy. 288. https://doi.org/10.4324/9780203968536

Prasetya, A. W. (2020). Menteri Desa PDTT Jelaskan Sebab Penyaluran Dana Desa Belum Maksimal. Kompas.Com.

https://amp.kompas.com/nasional/read/2020/04/08/19505051/menteri-desa-pdtt-jelaskansebab-penyaluran-dana-desa-belum-maksimal

Rika Gamayuni, R. (2020). Accounting information technology and village finance management in Indonesia. Journal of Administrative and Business Studies, 6(1), 1-8. https://doi.org/10.20474/jabs-6.1.1

Riyadi, W., \& Kurnadi, E. (2020). Pengaruh Pemanfaatan Teknologi Informasi , Partisipasi Penganggaran dan Pengawasan Terhadap Akuntabilitas Pengelolaan Dana Desa di Kecamatan Sindang Kabupaten Majalengka Influence of Information Technology Utilization, Budgeting Participation and Supervi. Jurnal Ekonomi Syariah Dan Bisnis, 3(2), 160-168. http://dx.doi.org/10.31949/mr.v3i2.2438

Setiyadi, M. W. R. (2003). Pemanfaatan teknologi informasi dalam penerapan good governance (Jakarta). Universitas Gunadarma. 
Good Governance on Village Fund Management with The Use of Information Technology as A Moderating Variable

Singh, S., \& Kaur, R. (2015). Good Governance: Expectations and Challenges. 1, 114-116. https://www.allresearchjournal.com/archives/2015/vol1 issue11/PartB/1-11-44.pdf

Siregar, T. (2018). Bupati dan Wakil Bupati Inhil Dimita Wujudkan Tata Kelola Pemerintahan yang Bersih. rri.co.id. https://m.rri.co.id/pekanbaru/daerah/601983/bupati-dan-wakil-bupatiinhil-diminta-wujudkan-tata-kelola-pemerintahan-yang-bersih

Sugiarti, E., \& Yudianto, I. (2017). Analisis Faktor Kompetensi Sumber Daya Manusia, Pemanfaatan Teknologi Informasi, dan Partisipasi Penganggaran Terhadap Akuntabilitas Pengelolaan Dana Desa. Proceedings Profesionalisme Akuntan Menuju Sustainable Business Practice, 3, 580-590.

Susliyanti, E. D. (2017). Transparansi dan Akuntabilitas Alokasi Dana Desa (Studi pada Desa Trimulyo, Kecamatan Jetis, Kabupaten Bantul Tahun 2015). Forum Keuangan Dan Bisnis V, 20(1), 261-271. http://fkbi.akuntansi.upi.edu/wp-content/uploads/2017/10/FKBIV_GVRC_02_Eni-Dwi-Susliyanti_Sekolah-Tinggi-Ilmu-Ekonomi-Solusi-BisnisIndonesia.pdf

Taufik, T., \& Safrizal. (2021). Factors That Influence the Village Financial Management with Aparature Commitments as Moderating Variables. Journal of Xidian University, 15(2). https://doi.org/10.37896/jxu15.2/002

Tumbel Mentari, S. (2014). Kecamatan Tareran. Partisipasi Masyarakat Dalam Pengelolaan Dana Desa Di Desa Tumaluntung Satu Kecamatan Tareran Kabupaten Minahasa Selatan.

Udomsilp, S. (2013). Information technology to strengthen local community tasks: Village fund and Elderly Payment System case studies. 13th International Symposium on Communications and Information Technologies: Communication and Information Technology for New Life Style Beyond the Cloud, ISCIT 2013, 772-775. https://doi.org/10.1109/ISCIT.2013.6645959

Utomo, K. S., Setio. S., \& Suharto, D. G. (2018). Analisis Good Governance Dalam Pengelolaan Keuangan Desa. Spirit Publik: Jurnal Administrasi Publik, 13(1), 50-66. https://doi.org/10.20961/sp.v13i1.22924

Van Slyke, D. M. (2007). Agents or stewards: Using theory to understand the governmentnonprofit social service contracting relationship. Journal of Public Administration Research and Theory, 17(2), 157-187. https://doi.org/10.1093/jopart/mul012

Wafirotin, K. Z., \& Septiviastuti, U. (2019). the Effect of Transparency, Community Participation, and Accountability on Management of Village Funds in Ponorogo Regency. Ekuilibrium: Jurnal Ilmiah Bidang Ilmu Ekonomi, 14(1), 31-44. https://doi.org/10.24269/ekuilibrium.v14i1.1527 